\title{
Eficiência de diferentes protocolos de extração de DNA em macieira
}

\author{
Efficiency of different protocols of apple tree DNA extraction
}

\section{Thyana Lays Brancher ${ }^{1 *}$, Maraisa Crestani Hawerroth ${ }^{2}$, Marcus Vinícius Kvitschal ${ }^{2}$ \& Danielle Caroline Manenti ${ }^{3}$}

\footnotetext{
${ }^{1}$ Universidade Federal de Lavras, Lavras, MG, Brasil. *Autor para correspondência: thyanalays@hotmail.com

${ }^{2}$ Empresa de Pesquisa Agropecuária e Extensão Rural de Santa Catarina, Caçador, SC, Brasil.

${ }^{3}$ Universidade Estadual de Maringá, Maringá, PR, Brasil.
}

Submissão: 20/09/2017 | Aceite: 13/06/2018

\begin{abstract}
RESUMO
Existem diversos protocolos para a extração de DNA vegetal, que proporcionam concentrações e qualidade variáveis de DNA em função da interação entre os componentes das soluções de extração e os compostos dos tecidos vegetais interferentes, como polifenois e proteínas. O objetivo da realização do trabalho foi testar a eficiência de protocolos de extração de DNA a partir de folhas de macieira. Testou-se três protocolos de extração de DNA: Kit FastDNA ${ }^{\circledR}$ SPIN da MP Biomedicals; adaptação a partir do Mini Kit DNeasy ${ }^{\circledR}$ Plant da Qiagen; adaptação do protocolo CTAB. Foram utilizadas folhas jovens frescas e congeladas dos genótipos M-10/09, SCS426 Venice e SCS427 Elenise. A pureza e a concentração das amostras de DNA obtidas foram analisadas em espectrofotômetro. O DNA foi testado via reações de PCR com o iniciador SAND, que acessa uma região do genoma da macieira associada a um fator de transcrição. As maiores concentrações de DNA foram proporcionadas pelo protocolo CTAB adaptado. Já quanto à pureza, considerou-se satisfatório o protocolo adaptado a partir do Mini Kit DNeasy ${ }^{\circledR}$ Plant e o CTAB adaptado, enquanto que todos os protocolos foram eficientes para a amplificação dos fragmentos alvo via reações de PCR. Dessa forma, os três protocolos podem ser utilizados para a extração de DNA de macieira a partir de folhas. Contudo, com a utilização do protocolo CTAB observou-se elevada eficácia, em razão da maior qualidade e concentração de DNA extraído, além do menor custo relativo no processo de extração.
\end{abstract}

PALAVRAS-CHAVE: Malus domestica, biologia molecular, tecido foliar, reação em cadeia da polimerase.

\begin{abstract}
Several protocols to extract plant DNA exist, which can provide varying concentrations and quality of DNA due to the interaction between the protocol components and plant tissue compounds that affect the extraction, such as polyphenols and proteins. The objective of this study was to test the efficiency of different protocols for extracting DNA from apple tree leaves. Three DNA extraction protocols were tested: FastDNA ${ }^{\circledR}$ SPIN Kit - MP Biomedicals; adaptation from Qiagen DNeasy ${ }^{\circledR}$ Plant Mini Kit; adapted CTAB. Fresh and frozen young leaves of the genotypes M-10/09, SCS426 Venice and SCS427 Elenise were used. The purity and concentration of the DNA were analyzed using a spectrophotometer. The DNA extracted was tested using PCR with one primer related to regions of the genome that access transcription factors in apples (SAND). The highest concentrations of DNA were provided by the adapted CTAB protocol. Regarding purity, the adaptation from Qiagen DNeasy ${ }^{\circledR}$ Plant Mini Kit and the adapted CTAB protocols were considered satisfactory. Regarding DNA quality verified by PCR, all protocols were efficient for amplification of the target fragments. Therefore, all three protocols can be used for DNA extraction from apple leaves; however, the use of the adapted CTAB protocol showed high efficiency, due to the higher quality and concentration of DNA, with the lowest relative cost in the process of DNA extraction.
\end{abstract}

KEYWORDS: Malus domestica, molecular biology, leaf tissue, polymerase chain reaction.

\section{INTRODUÇÃO}

A macieira (Malus domestica Borkh.) é uma espécie frutífera de elevada importância econômica e comercial em todo o mundo, sendo a maçã a terceira fruta mais produzida (FAOSTAT 2014). Devido ao aumento da exigência dos consumidores sobre a qualidade dos frutos, às mudanças climáticas e ao surgimento de novas doenças e pragas, o melhoramento genético de macieira se mostra fundamental para 
a continuação do cultivo de macieira em todo o mundo (BAUMGARTNER et al. 2016).

Nos últimos anos, as pesquisas de melhoramento genético com a cultura da macieira passaram a incluir técnicas de biologia molecular. A utilização dessas técnicas em macieira tem como finalidade principal otimizar a eficiência e o tempo empregado nas pesquisas, facilitando a seleção de genótipos promissores, em razão que é uma espécie perene e algumas características demandam muitos anos para serem devidamente caracterizadas (BIANCO et al. 2014, CUSIN et al. 2017, GUAN et al. 2015, ZHANG et al. 2014). Entretanto, a eficiência das análises utilizando as técnicas de biologia molecular depende da obtenção de DNA de qualidade, íntegro, com baixo nível de contaminantes e em quantidade suficiente para ser utilizado nos passos seguintes de cada processo (EDGE-GARZA et al. 2014).

A principal dificuldade para isolar o material genético de macieira se deve às plantas do gênero Malus possuírem alta concentração de metabólitos secundários, que interferem significativamente na qualidade e na quantidade do DNA extraído (AUBAKIROVA et al. 2014). Portanto, os protocolos de extração utilizados em macieira devem ser capazes de eliminar esses compostos interferentes, minimizando possíveis efeitos negativos nos processos seguintes nos quais o DNA será utilizado. Além disso, dá-se preferência a protocolos que sejam de baixo custo e de rápida realização, em razão da necessidade de se manipular um grande número de amostras. Sendo assim, visando agilidade, eficiência e economia, o melhor método de extração de DNA de macieira é aquele que proporciona maior quantidade e qualidade do material genético isolado, em função da integridade e pureza do DNA extraído.

Nesse sentido, teve-se como objetivo avaliar a eficiência de protocolos de extração de DNA vegetal aplicados à extração de DNA de folhas de macieira.

\section{MATERIAL E MÉTODOS}

O experimento foi realizado no Laboratório de Biotecnologia da Empresa de Pesquisa Agropecuária e Extensão Rural de Santa Catarina (Epagri), Estação Experimental de Caçador, em Caçador, SC. Testou-se três protocolos de extração de DNA de plantas: a) kit FastDNA ${ }^{\circledR}$ SPIN da marca MP Biomedicals (Kit FastDNA ${ }^{\circledR}$ Spin); b) protocolo adaptado por ANTANAVICIUTE et al. (2015) a partir do kit DNeasy ${ }^{\circledR}$ Plant da marca Qiagen (DNeasy adaptado); e c) protocolo de extração de DNA de folhas desenvolvido por LEFORT \& DOUGLAS (1999), com as modificações (REVERS et al. 2006) (CTAB adaptado) (Tabela 1).

$O$ delineamento experimental foi inteiramente casualizado, em esquema fatorial $3 \times 2$ (protocolo de extração de DNA e tipo de material vegetal), com 15 repetições, representadas por duas amostras de cada genótipo. O genótipo não foi considerado como fator de variação por não caracterizar o foco desta avaliação. Os dados foram submetidos à análise de variância e as médias comparadas pelo teste Tukey, a $5 \%$ de probabilidade.

Foram coletadas folhas jovens de três genótipos de macieira (seleção M-10/09, cultivar SCS426 Venice e cultivar SCS427 Elenise), com até $5 \mathrm{~cm}$ de comprimento, retiradas de estacas cuja brotação foi induzida artificialmente em câmaras de crescimento com umidade e temperatura controladas $(90 \pm 1,5 \% \mathrm{e}$ $25 \pm 1 \stackrel{\circ}{\circ}$ ). Metade das folhas coletadas foi acondicionada em sacos plásticos, devidamente identificados, e mantidas à - $20 \stackrel{\circ}{\circ} \mathrm{C}$ por sete dias (congeladas) antes da extração de DNA e a outra metade foi submetida aos protocolos de extração de DNA imediatamente após a coleta.

Em todos os protocolos utilizou-se $150 \mathrm{mg}$ de tecido vegetal, cuja maceração foi realizada no extrator da marca MP Biomedicals, com a programação padrão recomendada pelo fabricante para tecido foliar de pereira, que se assemelha ao tecido foliar de macieira ( $6 \mathrm{~m} \mathrm{~s}^{-1}$ por 40 segundos), utilizando o tubo Lysing Matrix A, específico desse aparelho.

Após a extração de DNA foi realizada a leitura da concentração e qualidade do DNA extraído em espectrofotômetro modelo S50 e microcubeta QuantiMate500, ambos da marca Biochrom, utilizando $5 \mu \mathrm{L}$ de amostra. Além disso, com a intenção de eliminar possíveis contaminações de RNA, todas as amostras foram tratadas com $2 \mu \mathrm{g}$ de RNase $\mathrm{A}$ (PureLink ${ }^{\mathrm{TM}}$ ) por $\mu \mathrm{L}$ de amostra de DNA, e incubadas à $37^{\circ} \mathrm{C}$ por 30 min. Os procedimentos de análise das amostras de DNA em espectrofotômetro e o tratamento com RNAse foram idênticos para os três protocolos utilizados. Após o tratamento e leitura, o DNA extraído foi mantido à $-20^{\circ} \mathrm{C}$ até a sua utilização.

- Kit FastDNA ${ }^{\circledR}$ Spin: Foram seguidas as orientações do fabricante do "Kit FastDNA ${ }^{\circledR}$ SPIN" para a extração do DNA (MPBIO 2016).

- DNeasy adaptado: A solução de lise celular (Tabela 1) foi aquecida à $60^{\circ} \mathrm{C}$ por 10 min no momento de sua utilização. O tecido foliar foi adicionado a cada tubo "Lysing Matrix A", juntamente com $400 \mu \mathrm{L}$ da solução de lise celular previamente aquecida. Após a maceração, os microtubos foram incubados em banho-maria a $65^{\circ} \mathrm{C}$ durante $10 \mathrm{~min}$, invertendo-os duas vezes durante o período de incubação (aos 5 e 9 
min). Posteriormente, $130 \mu \mathrm{L}$ da solução de purificação foram adicionados a cada tubo, os quais foram homogeneizados e mantidos à $-20^{\circ} \mathrm{C}$ por $10 \mathrm{~min}$. As amostras foram centrifugadas durante $5 \mathrm{~min}$ a 20.000 $g$ em temperatura ambiente (TA). O sobrenadante resultante foi transferido para um novo microtubo contendo $675 \mu \mathrm{L}$ da solução de precipitação gelada $\left(-20{ }^{\circ} \mathrm{C}\right)$, seguido por homogeneização com auxílio da micropipeta. As amostras foram centrifugadas durante $2 \mathrm{~min}$ a $6.000 \mathrm{~g}$ em TA. O sobrenadante foi descartado, o pellet foi lavado duas vezes com $500 \mu \mathrm{L}$ da solução da lavagem, e as amostras foram suavemente invertidas três a quatro vezes. Após cada uma das lavagens, as amostras foram centrifugadas a $6.000 \mathrm{~g}$ durante $1 \mathrm{~min}$ em TA. O pellet foi mantido em TA até a secagem completa e posteriormente ressuspendido em $100 \mu \mathrm{L}$ da solução de ressuspensão.

- CTAB adaptado: O material vegetal foi adicionado ao tubo "Lysing Matrix A", juntamente com $600 \mu \mathrm{L}$ de solução de lise celular (Tabela 1). Após a maceração das amostras, os tubos foram incubados em banhomaria a $60^{\circ} \mathrm{C}$ por $25 \mathrm{~min}$, invertendo-os a cada $\approx 6 \mathrm{~min}$. Em seguida, os tubos foram mantidos em TA por 5 min, sendo posteriormente adicionados $600 \mu \mathrm{L}$ da solução de purificação e homogeneizados gentilmente por inversão constante dos tubos durante $5 \mathrm{~min}$. As amostras foram centrifugadas a $10.000 \mathrm{~g}$ por $10 \mathrm{~min}$ em TA, sendo a fase aquosa $(\approx 450 \mu \mathrm{L})$ transferida para um novo microtubo. Ao microtubo com o líquido remanescente da etapa anterior foram adicionados $250 \mu \mathrm{L}$ de $\mathrm{NaCl} 5 \mathrm{M}$ e $750 \mu \mathrm{L}$ de isopropanol gelado $(-20$ $\left.{ }^{\circ} \mathrm{C}\right)$, sendo agitado vigorosamente e refrigerado $\left(4\right.$ a $\left.6{ }^{\circ} \mathrm{C}\right)$ por $20 \mathrm{~min}$. Após o período de incubação, as amostras foram centrifugadas a $10.000 \mathrm{~g}$ por $10 \mathrm{~min}$ em TA para precipitação do DNA. O sobrenadante foi descartado e o pellet lavado com $900 \mu \mathrm{L}$ de etanol $75 \%$ gelado $(-20 \stackrel{\circ}{\circ})$, sendo posteriormente seco em TA e ressuspendido em $100 \mu \mathrm{L}$ da solução de ressuspensão.

Tabela 1. Características das soluções que compõem os diferentes protocolos de extração de DNA de plantas de macieira testados.

Table 1. Characteristics of the solutions that make up the different DNA extraction protocols of apple plants tested.

\begin{tabular}{|c|c|c|c|}
\hline \multirow{2}{*}{ Solução } & \multicolumn{3}{|c|}{$\begin{array}{l}\text { Características da solução utilizada em cada protocolo de extração de DNA de } \\
\text { macieira }\end{array}$} \\
\hline & Kit FastDNA ${ }^{\circledast}$ Spin & DNeasy adaptado & CTAB adaptado \\
\hline $\begin{array}{l}\text { Solução de lise } \\
\text { celular }\end{array}$ & CLS-VF + PPS ${ }^{*}$ & $\begin{array}{l}\text { Triton X-100 2\%; SDS 1\%; } \\
\text { cloreto de sódio 0,5 M; cloridrato } \\
\text { de guanidina 0,5 M; Tris pH 8,0 } \\
100 \mathrm{mM} \text { e MOPS } 40 \mathrm{mM}\end{array}$ & $\begin{array}{c}\text { CTAB 1\%; PVP40 2\%; Tween } 20 \\
\text { 0,5\%; Tris-HCl pH 8,0 } 50 \text { mM; } \\
\text { EDTA } 20 \text { mM; cloreto de sódio 1,1 } \\
\text { M, cloreto de lítio 0,4 M; } \beta \text { - } \\
\text { mercaptoetanol } 0,2 \% \text { + PVPP }\end{array}$ \\
\hline $\begin{array}{l}\text { Solução de } \\
\text { purificação }\end{array}$ & Binding Matrix* & Acetato de potássio $5 \mathrm{M}$ & Clorofórmio: álcool isoamílico 24:1 \\
\hline $\begin{array}{l}\text { Solução de } \\
\text { precipitação }\end{array}$ & SEWS-M* & $\begin{array}{c}\text { Cloridrato de guanidina } 0,66 \mathrm{M} \mathrm{e} \\
\text { etanol } 63,3 \%\end{array}$ & $\begin{array}{l}\text { Cloreto de sódio } 5 \mathrm{M}+ \\
\quad \text { isopropanol*** }\end{array}$ \\
\hline $\begin{array}{l}\text { Solução de } \\
\text { lavagem }\end{array}$ & - & $\begin{array}{l}\text { Tris pH 8,0 } 10 \mathrm{mM} \text {; EDTA pH 8,0 } \\
1 \mathrm{mM} \text {; cloreto de sódio } 50 \mathrm{mM} \mathrm{e} \\
\text { etanol } 67 \%\end{array}$ & Etanol 75\% \\
\hline $\begin{array}{l}\text { Solução de } \\
\text { ressuspensão }\end{array}$ & DES* & $\begin{array}{c}\text { Tris-HCl pH 8,0 } 10 \mathrm{mM} \text { e EDTA } \\
\mathrm{pH} \mathrm{8,0} 0,5 \mathrm{mM}\end{array}$ & $\begin{array}{c}\text { Tris- } \mathrm{HCl} \mathrm{pH} \mathrm{8,0} 10 \mathrm{mM} \text { e EDTA } 1 \\
\mathrm{mM}\end{array}$ \\
\hline
\end{tabular}

*Solução comercial. **Não faz parte da solução. É adicionado à amostra logo após a aplicação da solução de lise celular. ${ }^{* * *}$ Solução de cloreto de sódio e o isopropanol são mantidas separadas.

\section{Avaliação da eficiência dos protocolos testados}

A eficiência dos protocolos de extração de DNA em macieira foi avaliada pela concentração $\left(n g \mu \mathrm{L}^{-1}\right)$ do DNA obtido e a respectiva pureza pelo quociente das leituras em espectrofotômetro nos comprimentos de onda 260 e $280 \eta \mathrm{m}\left(\mathrm{A}_{260} / \mathrm{A}_{280}\right)$, e 260 e $230 \mathrm{\eta m}\left(\mathrm{A}_{260} / \mathrm{A}_{230}\right)$. Esses comprimentos de onda correspondem à proteínas e outros contaminantes $(280 \eta \mathrm{m})$, compostos orgânicos, como fenóis $(230 \eta \mathrm{m})$ e ácidos nucleicos (260 ฤm) (DESJARDINS \& CONKLIN 2010).

Para testar a integridade do material genético resultante dos métodos de extração, as amostras de maior e menor concentração de DNA obtidas em cada uma das condições de avaliação (protocolo vs condição do material vegetal, para cada um dos três genótipos) foram submetidas à amplificação pela técnica de PCR utilizando um par de iniciadores para o gene referência "SAND" em macieira, referente a um fator de transcrição (Forward: TACTAATGTGCAAACACAAG; Reverse: TGATTCTGATGCCATGACAAAGT) (PERINI et al. 2014). 
As reações de PCR foram compostas por $1 \mathrm{U}$ de Taq DNA polimerase (Ludwig Biotec), tampão da enzima 1x, 2,00 mM de $\mathrm{MgCl}_{2}, 0,2 \mathrm{mM}$ de dNTPs, $1 \mu \mathrm{M}$ de cada iniciador (forward e reverse) e $50 \mathrm{ng}$ de DNA genômico. As reações foram conduzidas em termociclador $\mathrm{T} 100^{\mathrm{TM}}$ da marca Bio-Rad, com a seguinte configuração: 3 min a $94^{\circ} \mathrm{C}$, seguido por 35 ciclos compostos de $94^{\circ} \mathrm{C}$ por $1 \mathrm{~min}$, pareamento à $62{ }^{\circ} \mathrm{C}$ por 1 min e $72 \stackrel{\circ}{\circ} \mathrm{C}$ por $1 \mathrm{~min}$, seguindo-se de uma etapa final de extensão à $72{ }^{\circ} \mathrm{C}$ por 7 min e, mantendo-se a temperatura fixa em $4 \stackrel{\circ}{\circ}$ após a finalização do processo de amplificação.

Os produtos de amplificação foram analisados por eletroforese em gel de agarose $3 \%$ ( $80 \mathrm{~V}$ por 2 horas). As amostras foram coradas com o fluoróforo intercalante GelRed $^{\circledR}$ e a leitura do perfil dos fragmentos amplificados foi realizada mediante análise do gel por imagem capturada em fotodocumentador Kodak Geologic 2012 Pró.

\section{Estimativa de custo por amostra}

Para estimar o custo por amostra resultante dos diferentes protocolos de extração de DNA, os valores dos reagentes utilizados foram consultados junto às principais fornecedoras do Brasil (Sigma-Aldrich ${ }^{\circledR}$, Promega $^{\circledR}$, Interprise ${ }^{\circledR}$ e ThermoFisher ${ }^{\circledR}$ ). Enquanto o valor do kit FastDNA ${ }^{\circledR}$ SPIN foi cotado junto à empresa Síntese Biotecnologia, representante da marca MP Biomedicals no Brasil atualmente. Como informação adicional, o tempo aproximado de extração de DNA utilizado em cada protocolo foi estimado considerando unicamente o processo de extração, desconsiderando o tempo de preparo das soluções.

\section{RESULTADOS E DISCUSSÃO}

A qualidade das amostras de DNA foi influenciada pelo tipo de material vegetal (M) utilizado nos diferentes protocolos testados $(P)$, uma vez que se verificou interação $M \times P$ significativa para as relações $A_{260} / A_{280}$ e $A_{260} / A_{230}$. Contudo, a concentração de DNA obtida foi dependente apenas dos protocolos testados, não sofrendo efeito significativo da condição do tecido foliar utilizado e nem da interação entre esses fatores de variação.

Considerando a relação das absorbâncias $A_{260} / A_{280}$, todos os protocolos utilizados proporcionaram extração de DNA dentro do padrão de qualidade preconizado, tendo sido obtidos valores superiores a 1,8 (Tabela 2).

O uso do protocolo "CTAB adaptado" proporcionou a extração de amostras de DNA de melhor qualidade que os demais métodos testados, visto que a relação $A_{260} / A_{280}$ média $(2,137)$ foi superior em comparação ao uso do "DNeasy adaptado" $(2,045)$ e do "Kit FastDNA ${ }^{\circledR}$ Spin" $(1,835)$ (Tabela 2). Para o "Kit FastDNA ${ }^{\circledR}$ Spin", o uso de folhas frescas proporcionou relação $A_{260} / A_{280}$ superior ao das congeladas. O DNA extraído de folhas congeladas utilizando o protocolo "CTAB adaptado", por sua vez, proporcionou valor superior para a relação $A_{260} / A_{280}$ do que o DNA extraído de folhas frescas. $A$ relação $A_{260} / A_{280}$ das amostras extraídas com o uso do protocolo "DNeasy adaptado" não sofreu alteração em função do tipo de material vegetal utilizado.

De modo geral, para a relação de absorbâncias $A_{260} / A_{230}$, o uso dos protocolos "CTAB adaptado" e "DNeasy adaptado" também evidenciou a extração de amostras de DNA de boa qualidade, visto que as relações $A_{260 /} A_{230}$ foram superiores à 2,0. O protocolo "CTAB adaptado" proporcionou a extração de amostras de DNA de melhor qualidade, tendo sido a relação $A_{260} / A_{230}(2,384)$ superior em comparação aos demais (Tabela 2). AUBAKIROVA et al. (2014) realizaram testes de extração de DNA em macieira que incluíam dois protocolos semelhantes ao "CTAB adaptado", e obtiveram valores de $A_{260} / A_{280}$ variando entre 1,09 a 1,68, valores abaixo dos considerados ideais e aos valores encontrados nesta avaliação. $O$ uso de folhas congeladas proporcionou amostras de DNA com relação $A_{260} / A_{230}$ superior $(1,600)$ ao uso de folhas frescas $(1,526)$. Apenas para o protocolo "DNeasy adaptado" o tipo de tecido, fresco ou congelado, interferiu na qualidade da amostra de DNA extraído, sendo observada a relação $A_{260} / A_{230}$ superior mediante o uso de folhas congeladas $(2,186)$ em detrimento à de folhas frescas $(2,002)$. Uma vez que os valores das relações de absorbâncias $A_{260} / A_{280}$ e $A_{260} / A_{230}$ considerados ideais quanto à qualidade das amostras de DNA são acima de 1,8 e 2,0, respectivamente (ANTANAVICIUTE et al. 2015, CHENG et al. 1997, DESJARDINS \& CONKLIN 2010), pode-se inferir que o "Kit FastDNA ${ }^{\circledR}$ Spin" foi o protocolo menos eficiente para a extração de DNA em macieira, principalmente em função das médias de $A_{260} / A_{230}$ terem sido muito abaixo de 2,0.

De modo geral, para a relação de absorbâncias $A_{260} / A_{230}$, o uso dos protocolos "CTAB adaptado" e "DNeasy adaptado" também evidenciou a extração de amostras de DNA de boa qualidade, visto que as relações $A_{260} / A_{230}$ foram superiores à 2,0. O protocolo "CTAB adaptado" proporcionou a extração de amostras de DNA de melhor qualidade, tendo sido a relação $A_{260} / A_{230}(2,384)$ superior em comparação aos demais (Tabela 2). AUBAKIROVA et al. (2014) realizaram testes de extração de DNA em macieira que incluíam dois protocolos semelhantes ao "CTAB adaptado", e obtiveram valores de $A_{260} / A_{280}$ variando entre 
1,09 a 1,68, valores abaixo dos considerados ideais e aos valores encontrados nesta avaliação. O uso de folhas congeladas proporcionou amostras de DNA com relação $A_{260} / A_{230}$ superior $(1,600)$ ao uso de folhas frescas $(1,526)$. Apenas para o protocolo "DNeasy adaptado" o tipo de tecido, fresco ou congelado, interferiu na qualidade da amostra de DNA extraído, sendo observada a relação $A_{260} / A_{230}$ superior mediante o uso de folhas congeladas $(2,186)$ em detrimento à de folhas frescas $(2,002)$. Uma vez que os valores das relações de absorbâncias $A_{260} / A_{280}$ e $A_{260} / A_{230}$ considerados ideais quanto à qualidade das amostras de DNA são acima de 1,8 e 2,0, respectivamente (ANTANAVICIUTE et al. 2015, CHENG et al. 1997, DESJARDINS \& CONKLIN 2010), pode-se inferir que o "Kit FastDNA ${ }^{\circledR}$ Spin" foi o protocolo menos eficiente para a extração de DNA em macieira, principalmente em função das médias de $A_{260} / A_{230}$ terem sido muito abaixo de 2,0.

Tabela 2. Qualidade e concentração de DNA em amostras de DNA obtidas utilizando diferentes protocolos de extração a partir de folhas frescas e folhas congeladas de macieira.

Table 2. Quality and concentration of DNA samples obtained using different extraction protocols from fresh leaves and frozen leaves of apple trees.

Relação $A_{260} / A_{280}$

\begin{tabular}{lcccc}
\hline \multirow{2}{*}{ Tipo de material vegetal } & \multicolumn{4}{c}{ Protocolo de extração de DNA de macieira } \\
\cline { 2 - 5 } & Kit FastDNA $^{\circledR}$ Spin & DNeasy adaptado & CTAB adaptado & Média \\
\hline Folha fresca & $1,854 \mathrm{Ac}$ & $2,030 \mathrm{Ab}$ & $2,121 \mathrm{Ba}$ & $2,002 \mathrm{~A}$ \\
Folha congelada & $1,816 \mathrm{Bc}$ & $2,061 \mathrm{Ab}$ & $2,153 \mathrm{Aa}$ & $2,010 \mathrm{~A}$ \\
\hline Média & $1,835 \mathrm{c}$ & $2,045 \mathrm{~b}$ & $2,137 \mathrm{a}$ & - \\
\hline
\end{tabular}

Relação $A_{260} / A_{230}$

\begin{tabular}{lcccc}
\hline \multirow{2}{*}{ Tipo de material vegetal } & \multicolumn{4}{c}{ Protocolo de extração de DNA de macieira } \\
\cline { 2 - 6 } & Kit FastDNA ${ }^{\circledR}$ Spin & DNeasy adaptado & CTAB adaptado & Média \\
\hline Folha fresca & $0,222 \mathrm{Ac}$ & $2,002 \mathrm{Bb}$ & $2,354 \mathrm{Aa}$ & $1,526 \mathrm{~B}$ \\
Folha congelada & $0,200 \mathrm{Ac}$ & $2,186 \mathrm{Ab}$ & $2,414 \mathrm{Aa}$ & $1,600 \mathrm{~A}$ \\
\hline Média & $0,211 \mathrm{c}$ & $2,094 \mathrm{~b}$ & $2,384 \mathrm{a}$ & -- \\
\hline
\end{tabular}

Concentração de DNA na amostra (ng $\left.\mu \mathrm{L}^{-1}\right)$

\begin{tabular}{|c|c|c|c|c|}
\hline & \multicolumn{4}{|c|}{ Protocolo de extração de DNA de macieira } \\
\hline & Kit FastDNA ${ }^{\circledR}$ Spin & DNeasy adaptado & CTAB adaptado & Média \\
\hline Média & $285,44 \mathrm{c}$ & $819,24 b$ & $2405,74 \mathrm{a}$ & -- \\
\hline
\end{tabular}

Médias seguidas da mesma letra maiúscula na coluna e minúscula na linha não diferem significativamente entre si pelo teste de Tukey a $5 \%$ de significância.

Compostos identificados no comprimento de onda $280 \mathrm{~nm}$ são, em grande parte, proteínas e outros contaminantes (DESJARDINS \& CONKLIN 2010) que, possivelmente, não foram eliminados e/ou extraídos juntamente com o DNA mediante o uso dos três protocolos testados nessa avaliação. Entretanto, em 230 $\eta m$ são identificados compostos orgânicos, como fenóis (DESJARDINS \& CONKLIN 2010). Como a macieira é rica em compostos identificados em ambas as faixas de leitura no espectrofotômetro, sugere-se que os reagentes que compõem o "Kit FastDNA ${ }^{\circledR}$ Spin" não são eficientes para a separação e retirada dos mesmos, resultando em menor qualidade das amostras de DNA extraído, representada pelas relações $\mathrm{A}_{260} / \mathrm{A}_{280}$ e $\mathrm{A}_{260} / \mathrm{A}_{230}$.

Quanto a concentração de DNA obtido (Tabela 2), o uso do protocolo "CTAB adaptado" proporcionou maior concentração de DNA $\left(2405,74 \eta \mathrm{ng} \mathrm{L}^{-1}\right)$, seguido pelo protocolo "DNeasy adaptado" $\left(819,24 \eta \mathrm{ng} \mathrm{LL}^{-1}\right)$

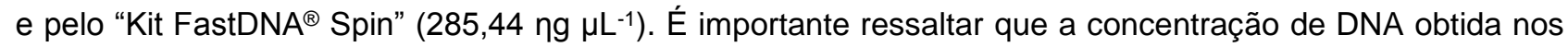
três protocolos não foi influenciada pelo tipo de material vegetal utilizado, o que possibilita a utilização de folhas frescas ou congeladas à $-20^{\circ} \mathrm{C}$, sem a obrigatoriedade de congelamento à $-80^{\circ} \mathrm{C}$. Este é um aspecto que permite maior flexibilidade na utilização desse tipo de protocolo, considerando que muitas vezes as amostras são coletadas em pomares distantes dos laboratórios, não sendo possível a extração imediata ou 
armazenamento à $-80 \stackrel{\circ}{\circ}$.

Considerando que em todos os protocolos foram utilizados $150 \mathrm{mg}$ de material vegetal, o rendimento

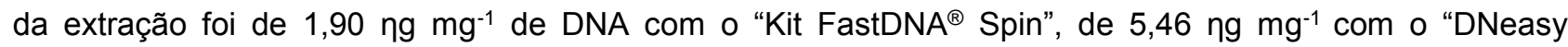
adaptado" e de 16,04 ng $\mathrm{mg}^{-1}$ com o "CTAB adaptado". CHENG et al. (1997) realizaram testes utilizando um protocolo similar ao protocolo "CTAB adaptado" e obtiveram concentrações de DNA entre 10 e 35 ng mg-1 de tecido vegetal em diferentes espécies, entre elas o gênero Malus, confirmando a boa eficiência do "CTAB adaptado" para extração de DNA de macieira.

Observando-se os produtos da PCR para o gene SAND em gel de agarose 3\% (Figura 1) pode-se verificar que as amostras extraídas com os três protocolos testados apresentaram resultados satisfatórios, caracterizados por bandas nítidas, tanto para amostras de menor quanto de maior concentração de DNA.

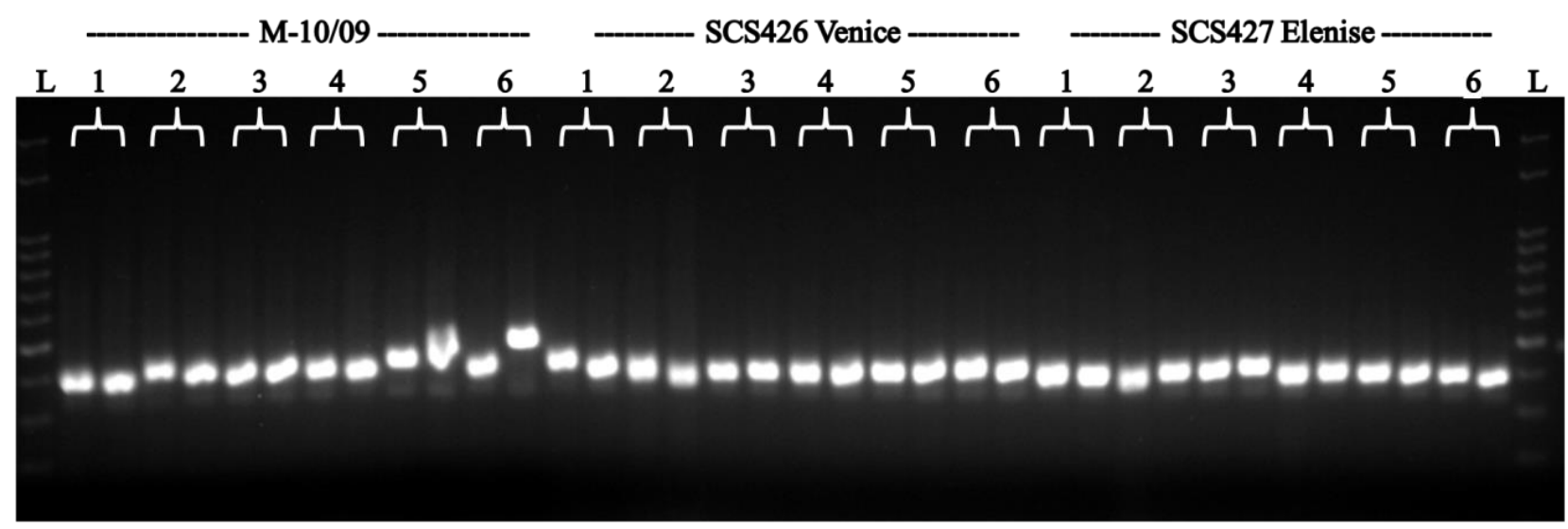

Figura 1. Gel de agarose 3\% após a eletroforese dos produtos das reações de PCR com o gene SAND realizadas utilizando as amostras de DNA de maior e menor concentração a partir de folhas frescas e congeladas, respectivamente, em cada protocolo testado, para cada genótipo de macieira considerado. L: Marcador de peso molecular de 50 pb; 1: Folhas frescas, utilizando o protocolo "Kit FastDNA ${ }^{\circledR}$ Spin"; 2: Folhas congeladas utilizando o protocolo "Kit FastDNA ${ }^{\circledR}$ Spin"; 3: Folhas frescas utilizando o protocolo "DNeasy adaptado"; 4: Folhas congeladas utilizando o protocolo "DNeasy adaptado"; 5: Folhas frescas utilizando o protocolo "CTAB adaptado"; 6: Folhas congeladas utilizando o protocolo "CTAB adaptado".

Figure 1. Agarose gel (3\%) after the electrophoresis of the PCR products performed using the highest and lowest concentration DNA samples from fresh and frozen leaves, respectively, in each protocol tested, for each apple genotype considered. L: 50 bp molecular weight marker; 1: Fresh leaves using the "FastDNA ${ }^{\circledR}$ Spin Kit" protocol; 2: Frozen leaves using the "FastDNA ${ }^{\circledR}$ Spin Kit" protocol; 3: Fresh leaves using the "adapted DNeasy" protocol; 4: Frozen leaves using the "adapted DNeasy protocol; 5: Fresh leaves using the "adapted CTAB Adapted" protocol; 6: Frozen leaves using the "adapted CTAB" protocol.

Considerando o custo médio e o tempo para a execução de cada protocolo, a extração de DNA realizada com o "Kit FastDNA ${ }^{\circledR}$ Spin" foi a mais rápida, sendo dedicados 45 min para uma bateria de 10 amostras, porém apresentou um custo elevado (aproximadamente $\mathrm{R} \$ 26,50$ por amostra). Para o protocolo "DNeasy adaptado", o preço médio de cada amostra foi de $\mathrm{R} \$ 1,82$, sendo realizado em aproximadamente 1 hora e 30 min (bateria de 10 amostras). Na execução do protocolo "CTAB adaptado" foram gastos aproximadamente 3 horas e 30 min para a extração de DNA de 10 amostras, a um custo de R\$3,95 cada.

Comparativamente, para se obter a mesma quantidade de DNA fornecida pelo uso do protocolo "CTAB adaptado" seriam necessárias aproximadamente oito extrações utilizando o protocolo "Kit FastDNA ${ }^{\circledR}$ Spin", a um custo total equivalente a R\$ 223,35. Já com o "DNeasy adaptado" seriam necessárias aproximadamente três extrações (custo total aproximado de $\mathrm{R} \$ 5,46$ ). Esses valores sugerem que a maior demanda de tempo para a realização do "CTAB adaptado" é compensada pela elevada concentração de DNA obtida ao final do processo, resultando em uma maior eficiência e economia em comparação aos demais protocolos testados.

\section{CONCLUSÃO}

Os três protocolos testados podem ser utilizados para a extração de DNA a partir de folhas de macieira. Porém, o protocolo "CTAB adaptado" proporcionou melhor custo-benefício e qualidade, bem como 
maior concentração de DNA extraído, sugerindo maior eficiência para utilização na extração de DNA de macieira a partir de tecido foliar.

\section{AGRADECIMENTOS}

Os autores agradecem à EPAGRI, à FAPESC, à UDESC, à FINEP, à CAPES e ao CNPq pelo fomento à pesquisa e financiamento de bolsas de estudo.

\section{REFERÊNCIAS}

ANTANAVICIUTE L et al. 2015. An inexpensive and rapid genomic DNA extraction protocol for rosaceous species. Journal of Horticultural Science and Biotechnology 90: 427-432.

AUBAKIROVA K et al. 2014. Evaluation of five protocols for DNA extraction from leaves of Malus sieversii, Vitis vinifera, and Armeniaca vulgaris. Genetics and Molecular Research 13: 1278-1287.

BAUMGARTNER IO et al. 2016. Development of SNP-based assays for disease resistance and fruit quality traits in apple (Malus $\times$ domestica Borkh.) and validation in breeding pilot studies. Tree Genetics \& Genomes 12:35.

BIANCO L et al. 2014. Development and validation of a $20 \mathrm{~K}$ single nucleotide polymorphism (SNP) whole genome genotyping array for apple (Malus $x$ domestica Borkh). Plos One 9: 1-9.

CHENG FS et al. 1997. A DNA extraction protocol from various tissues in woody species. HortScience 32: 921-922.

CUSIN R et al. 2017. New biotechnological tools to accelerate scab-resistance trait transfer to apple. Genetics and Molecular Biology 40: 305-311.

DESJARDINS P \& CONKLIN D. 2010. NanoDrop microvolume quantitation of nucleic acids. Journal of Visualized Experiments 45: 2565.

EDGE-GARZA DA et al. 2014. A high-throughput and cost-efficient DNA extraction protocol for the tree fruit crops of apple, sweet cherry, and peach relying on silica beads during tissue sampling. Molecular Breeding 34: 2225-2228.

FAOSTAT. 2014. Food and Agriculture Organization of The United Nations Statistics Database. Prodution/Crops. Disponível em: http://www.fao.org/faostat/en/\#data/QC. Acesso em: 24 jul. 2017.

GUAN Y et al. 2015. QTLs detected for individual sugars and soluble solids content in apple. Molecular Breeding 35: 1 13.

LEFORT F \& DOUGLAS GC. 1999. An efficient micro-method of DNA isolation from mature leaves of four hardwood tree species Acer, Fraxinus, Prunus and Quercus. Annals of Forest Science 56: 259-263.

MPBIO. 2016. Application manual FastDNA ${ }^{\circledR}$ SPIN Kit. Disponível em: https://www.mpbio.com/includes/protocol/FastDNA\%20SPIN\%20kit.pdf. Acesso em: 24 jul. 2017.

PERINI P et al. 2014. Reference genes for transcriptional analysis of flowering and fruit ripening stages in apple (Malus $\times$ domestica Borkh.). Molecular Breeding 34: 829-842.

REVERS LF et al. 2006. Uso prático de marcadores moleculares para seleção assistida no melhoramento de uvas de mesa apirênicas. Revista Brasileira de Fruticultura 28: 104-108.

ZHANG XJ et al. 2014. A and MdMYB1 allele-specific markers controlling apple (Malus $x$ domestica Borkh.) skin color and suitability for marker-assisted selection. Genetics and Molecular Research 13: 9103-9114. 